\title{
Reconstruction of People's Stories as a Potential Development of Regional Edu Tourism
}

\author{
Mukh Doyin ${ }^{1}$, Suseno ${ }^{2}$, Zuliyanti ${ }^{3}$ \\ Universitas Negeri Semarang ${ }^{1,2,3}$ \\ \{mukhdoyin@mail.unnes.ac.id ${ }^{1}$, suseno@mail.unnes.ac.id², zuliyanti@mail.unnes.ac.id³
}

\begin{abstract}
Folklore is a cultural feature that contains the philosophy of community life. The distribution is done orally, so it tends not to be well documented. There are also various versions of the story so that it can develop and have multiple interpretations even though the noble values in folklore can form a cultured generation. Therefore, it needs to be reconstructed and well documented. Folklore as national culture synergizes with regional tourism. Central Java's educational potential is still not growing rapidly. This is in line with the spread of folklore in Central Java which is still limited to certain areas. As technology develops, the spread of folklore reconstruction can be carried out in a more effective manner. Reconstruction of folklore can be a means to develop educational tourism which is currently developing in various regions including Central Java. Education needs to be developed to improve the economy of the people in an area. Natural and tourism resources need to be optimized and redeveloped by introducing folklore in the area. Folklore that develops can increase the attractiveness of tourists to visit. The expected tourism is not only looking for fun, but also learning while traveling.
\end{abstract}

Keywords: people's stories, edu tourism

\section{Introduction}

Oral traditions developed rapidly in various areas including folk tales. Folklore is a manifestation of human creativity that lives in the collectivity of society [1]. The spread of folklore is carried out orally and is still limited to certain local communities. This means that ancestral values in folklore are still limited to certain cultural features of the community. Folklore, which is oral and not well documented, has a tendency to quickly become extinct. This condition correlates with a very wide variety of folk tales and various versions. Variations in folklore will affect the content and content of the folklore to be different. This is a concern if the content and values in folklore are not conveyed properly to the public. In fact, folklore plays an important role in passing on ancestral values, ideas, and life philosophy for the community.

Folklore only develops in the older generation and has not been able to spread well to several generations. It is feared that it will disappear and not be well preserved for the younger generation. By looking at these conditions, the folklore should be reconstructed and documented properly so that it becomes a cultural asset of the nation and the preservation of 
cultural conservation. Folklore is synonymous with the culture of a particular society. Folk stories that develop in society include legends, myths, sages, fables, and others. This story is closely related to events or legacies that are still preserved in several areas which are now tourist attractions. It is not surprising that some areas have many historical places that are told in folklore and are currently developing into tourist areas.

The development of tourist areas is currently an asset whose potential must be developed to preserve culture and improve the regional economy and local residents. The rise of social media plays a role in developing tourist areas. It is not surprising that the surrounding communities have started to develop and explore the tourism potential in their respective regions. Most of the tourism in Central Java still does not carry the concept of education. Education has great potential to develop a tourist area. The development of education is not only focused on the sights for tourists, but is integrated with the educational elements in it. It is intended that visitors, apart from enjoying the scenery, also gain knowledge and knowledge, especially legends or folk tales that developed in these tourist attractions. In addition, the values contained in the folklore can be passed on and preserved to all visitors. By looking at these conditions, the reconstruction of folklore has great potential to be presented in the development of regional education.

\section{Reconstruction of People's Stories}

Folklore is originally an event of spoken language being spoken, not written down. As speech, folklore works with and through a combination of the various qualities of the human voice, for example, vowels and consonants, voice pitches, sound lengths, pauses, stress, tone of voice, and so on. Folklore as an oral/spoken event involves the storyteller and listener in an interactive, dialogical manner. Storytellers and listeners are present and actively involved in the same space and time, both parties influence each other [2]. Folklore is some part of the oral tradition that lives in society. These folk tales were transmitted orally from our ancestors to the present day. These oral traditions make folklore easy to disappear and disappear from cultural civilization. Folklore is a reflection of the life of the old society, whether it is in the form of fairy tales, myths, sage, or legends[3]. Folklore has not been well documented. The stories are also diverse and very varied so that from one story to another, it varies.

It is feared that this difference will affect the content and moral values contained in the folklore. Folklore contains the values of life that the older generation wants to convey to the younger generation through stories that reflect the values of life. Folklore as a miniature complex life is rich in humanistic values. Folklore is a literary work that contains humanism ethics which can be used to foster a sense of humanity in humans [4].

As a result of culture, these folk tales have functions as an expression of thoughts, attitudes, and values of life that are very useful for the local community. More than that, the fact in society that the values and traditions contained in the oral traditions that live there are starting to be abandoned [5]. Seeing these conditions, the folklore that is currently developing in society is urgent to be reconstructed. Reconstruction of the people can be done by collecting, identifying and reconstructing the folk tales. The results of the reconstruction are documented by taking inventory into a book.

The purpose of reconstructing these folk tales is first, to properly document the folklore that develops in the community and classify them according to story categories. Second, to introduce and spread the moral values contained in these folk tales. It is hoped that these values can be taught and carried to the younger generation so that the noble values of the 
nation's culture will never fade. Third, to protect the nation's cultural heritage. Folklore is a national cultural heritage that must be properly preserved and preserved. Thus it can be concluded that the reconstruction of folklore is very important to do to preserve and preserve folklore which is almost extinct.

\section{Rekonstruksi Cerita Rakyat dalam Pengembangan Eduwisata}

Reconstruction of folklore is one way to preserve the nation's culture. Folklore is a cultural asset that is rich in the noble values of the nation's culture. Folklore as a reflection of the culture of a particular society often contains stories of figures, regional origins, fairy tales, and others. The story is inseparable from the story of a certain area and is related to a place. The areas that appear in folklore, mostly developed as tourist areas. The development of tourist areas is rife in every city and province. It aims to develop culture and improve the economy of an area and its people. Educational development is currently needed to introduce culture and noble values as a provision for life. However, until now, education has become a dream that has not been realized properly.

Eduwisata means education and tourism, both of which are different, but synergize and complement each other. Education or also known as education is "any effort that is planned to influence other people, be it individuals, groups, or the community so that they do what is expected by the actors of education" [6]. Education is a necessity for everyone, so an interesting and fun delivery method is needed, so that the educational process can run optimally. Tourism is a trip or as part of these activities carried out voluntarily and temporarily to enjoy tourist objects and attractions.

Education can be defined as a tourism activity carried out by tourists and the main objective is to obtain education and learning [7]. Eduwisata is "a form of tourism activity that supports the study of visitors" [8]. Eduwisata can also be defined as a program that provides opportunities for tourists to carry out tourism activities that prioritize educational elements in certain places and the main objective is to gain learning experiences [9]. Tourists are not only treated to tourist objects, cultural activities, or interesting attractions, but also learning for learning practices, including learning history, getting to know culture, and the practice of making various skills.

Referring to this statement, folklore that has developed in the community can be used as a means to develop existing education and tourism areas that are not well developed. Folklore can be used as a means of promotion to the community so that they are more familiar with and have their own charm. The development of folklore carried out orally can facilitate the dissemination of information about the development of education. In addition, tourists' interest can also arise from the existence of a developing folklore. Therefore, the development of folklore through the reconstruction of folklore is expected to be one of the means to develop education.

\section{Conclusion}

Folklore with its oral nature and not well documented has a tendency to quickly become extinct, so it needs to be reconstructed. Reconstruction of the people can be done by collecting, identifying and reconstructing the folk tales. The results of the reconstruction are documented by taking inventory into a book. The objectives of reconstructing folk tales are (1) 
documenting folklore, (2) introducing and spreading the moral values contained in folklore, and (3) protecting the nation's cultural heritage. Folklore reconstruction can be used as a support for developing educational tours. Reconstruction of folklore can be a means to promote developing education and introduce the noble values of life to tourists so as to create a civilized and cultured community life.

\section{References}

[1] Zuhdi, Susanto. Budaya Maritim, Kearifan Lokal, dan Diaspora Buton. Laporan Penelitian Hibah Riset Strategi Nasional kepada DM-UI; (2016).

[2] Simatupang, G. R. Lono Lastoro. Penelitian Cerita Rakyat. Makalah disampaikan dalam Kegiatan Peningkatan Mutu Tenaga Teknis Balai Bahasa Yogyakarta, di Hotel University, Sleman, 2-3 November; (2011).

[3] Setiartin, Titin R. Transformasi Teks Cerita Rakyat ke dalam Bentuk Cerita Bergambar sebagai Model Pembelajaran Membaca Apresiatif. Dimuat dalam Jurnal LITERA, Volume 15, Nomor 2, Oktober; (2016).

[4] Thohiroh, Zulaifatut, U'um Qomariyah, dan Mukh Doyin. Etika Humanisme dalam Cerita Rakyat di Kabupaten Jepara. Dimuat dalam Jurnal Sastra Indonesia Juli 2017. http://journal.unnes.ac.id/sju/index.php/jsi; (2017).

[5] Gusal, La Ode. Nilai-Nilai Pendidikan dalam Cerita Rakyat Sulawesi Tenggara Karya La Ode Sidu. Dimuat dalam Jurnal Humanika No. 15, Vol. 3, Desember; (2015).

[6] Priyanto, Rahmat, Didin Syarifuddin, dan Sopa Martina. Perancangan Model Wisata Edukasi di Objek Wisata Kamung Tulip. Jurnal Abdimas BSI: Jurnal Pengabdian Kepada Masyarakat. Hal 32-38. http://ejournal.bsi.ac.id/ejournal/index.php/abdimas; (2018).

[7] Tim STP ARS Internasional dan AKPAR BSI Bandung. Buku Pandungan Wisata Edukasi Kaampung Tulip. Bandung: STP ARS Internasional dan AKPAR BSI Bandung; (2017).

[8] Aminudin, Asnawin. Menggagas: Eduwisata dan Desa Wisata di Takalar. Dimuat dalam Tabloid lintas-makasar.httml; (2014).

[9] Kurniati, Desna. Potensi Pengembangan Agrowisata sebagai Kawasan Eduwisata Lokal di Agrowisata Cilangkap Jakarta Timur. Skripsi. Universitas Islam Negeri Syarif Hidayatullah; (2015). 